\title{
2-Alkylation of 3-Alkyindoles With Unactivated Alkenes
}

\author{
Xuling Pan *, Qian Liu and Yingling Nong \\ State Key Laboratory Breeding Base of Green Pesticide and Agricultural Bioengineering, Key Laboratory of Green Pesticide and \\ Agricultural Bioengineering Ministry of Education, Guizhou University, Guiyang, China
}

An acid-catalyzed 2-alkylation of indole molecules is developed. Only catalytic amount of the commercially available, inexpensive and traceless $\mathrm{HI}$ is used as the sole reaction promoter. 2,3-Disubstituted indole molecules bearing congested tertiary carbon centers are afforded as the final products in moderate to excellent yields.

Keywords: metal-free, acid catalysis, atom economy, indole-2-alkylation, alkene

\section{INTRODUCTION}

Indole and its derivatives are versatile molecules and have found significant applications in biological and medicinal research ( $\mathrm{Ma}$ et al., 2016) (Figure 1A). For example, the indole derivative neoechinulin A has been isolated from P. griseofulvum and Aspergillus sp. and shown significant cytotoxic activity against P388 cells (Ma et al., 2016). Typrostatin A and B can be obtained from A. fumigatus, which is present in the sea sediment and the Ficus carica in both Japan and China. They

OPEN ACCESS

Edited by: Yaqiong Su,

Xi'an Jiaotong University, China

Reviewed by: Xingkuan Chen, Jinan University, China Xing Yang, Hunan Normal University, China

*Correspondence: Xuling Pan PanXL1996@163.com

Specialty section: This article was submitted to Organic Chemistry, a section of the journal

Frontiers in Chemistry

Received: 23 January 2022 Accepted: 28 January 2022 Published: 24 February 2022

Citation:

Pan X, Liu Q and Nong Y (2022) 2Alkylation of 3-Alkyindoles With Unactivated Alkenes.

Front. Chem. 10:860764. doi: 10.3389/fchem.2022.860764 have exhibited excellent antiphytopathogenic activity and have been used in the investigation of novel anti-tumor reagents (Ma et al., 2016). Therefore, the development of simple and efficient methods for functionalization of indole molecules is attractive and important to both scientific research and drug manufacturing.

Indole can be functionalized at each position around its aromatic structure through various transformations. Traditionally, the C3-positions of indole molecules have been widely used as nucleophiles to react with a variety of electrophiles in both enantioselective (Austin and MacMillan et al., 2002; Zhou and Tang et al., 2002; Evans et al., 2005; Wang et al., 2006; Terada et al., 2007; Bandini et al., 2009; Joucla and Djakovitch et al., 2009; Bartoli et al., 2010) and non-chiral fashion (Bartoli et al., 2005; Kimura et al., 2005; Moran et al., 2006; Kusurkar et al., 2008; Lerch et al., 2014). Transition metals, amines and Lewis acids are frequently used as effective catalysts for these reactions. The C2-positions of the $\mathrm{N}$-protected indoles can undergo transition metal-catalyzed alkylations (Doyle et al., 2010; Johansen and Kerr et al., 2010; Jiao and Bach et al., 2011; Pan et al., 2012; Lin et al., 2013; Yoshino et al., 2013; Su et al., 2014; Soni et al., 2018; Wang and Wang, 2021), arylations (Lane and Sames, 2004; Wang et al., 2005; Deprez et al., 2006; Lebrasseur and Larrosa et al., 2008; Phipps et al., 2008; Yang et al., 2008; Ackermann and Lygin, 2011; Sauermann et al., 2011; Li et al., 2016; Yang and Shi, 2018), alkenylations (Nakao et al., 2006; Maehara et al., 2008; Ding and Yoshikai, 2012; Li et al., 2013a; Li et al., 2013b; Liang et al., 2014; Schramm et al., 2015; Wong et al., 2015; Zhang W et al., 2015; Zhou et al., 2016), alkynylations (Yang et al., 2010; Tolnai et al., 2013; Sauermann et al., 2015; Zhang Z Z et al., 2015; Kong et al., 2016), aminations (Sun et al., 2014; Sun et al., 2015) and thiolation reactions (Gensch et al., 2016). A directing group is generally required to be installed on the $N$ atom of the indole molecule for the $\mathrm{C} 2$-functional group introductions in these transformations. In contrast, intermolecular reactions for direct functionalization of the $\mathrm{C} 2$-positions of the unprotected indoles have been relatively less developed (Figure 1B). Success within this direction includes the transition metal-catalyzed indole C2-alkylations with alkyl halides (Straathof et al., 2014; 
A bioactive natural products containing indole scafolds:<smiles>C=CC(C)(C)c1[nH]c2ccccc2c1/C=C1\NC(=O)[C@H](C)NC1=O</smiles>

neoechinulin $\mathrm{A}$ isolated from

$P$. griseofulvum \& Aspergillus sp.

- cytotoxic activity

- radical-scavenging activity<smiles>[R]c1ccc2c(C[C@@H]3NC(=O)[C@@H]4CCCN4C3=O)c(CC=C(C)C)[nH]c2c1</smiles>

$\mathrm{R}=\mathrm{OCH}_{3}:$ typrostatin $\mathrm{A} \& \mathrm{R}=\mathrm{H}$ : typrostatin $\mathrm{B}$ isolated from $A$. fumigatus

- microtubule assembly inhibitor

- antiphytopathogenic activity

$B$ methods for C2-functionalization of indoles:

transition metal catalysis

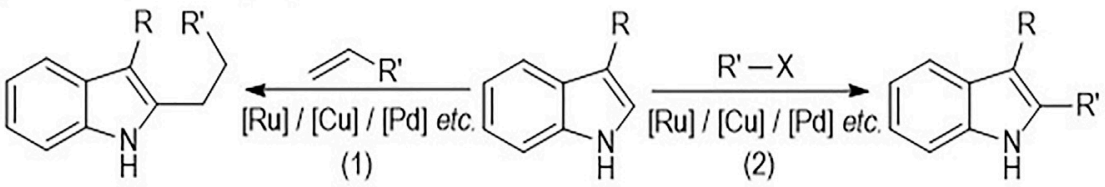

Melchiorre et al.<smiles>[R]c1cc([N+](=O)[O-])ccc1Cc1[nH]c2ccccc2c1CC1CC1</smiles><smiles>[R]c1c[nH]c2ccccc12</smiles><smiles>CCOC(=O)C(Br)C(=O)OCC</smiles><smiles>C=C(O)c1ccc(-c2cccs2)c2nn(C)nc12</smiles><smiles>[R]c1c(C(C(=O)OCC)C(=O)OCC)[nH]c2ccccc12</smiles>

Glorius et. al. $\int$ (photocat.)<smiles>[R]c1c[nH]c2ccccc12</smiles><smiles></smiles>

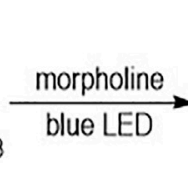<smiles>[R]c1c(C(C)C(C)=O)[nH]c2ccccc12</smiles>

C this work - indole C2-alkylation with alkenes promoted by $\mathrm{HI}$ acid:<smiles>Fc1c[nH]c2ccccc12</smiles><smiles>[R]C1CC1</smiles><smiles>[R]C=CC</smiles><smiles>[R]C(=C)Br</smiles>

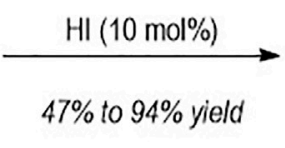<smiles>[R]c1c(C([R])([R])[Ga])[nH]c2ccccc12</smiles>

- traceless \& inexpensive acid catalyst - excellent atom-economy

- exclusive C2-regioselectivity - C2-branched alkylation products

FIGURE 1 | Bioactive Indole Derivatives bearing C2-Substituents and C2-Functionalizations of Unprotected Indoles.

Shao et al., 2015; Yang et al., 2015) and alkenes (Weng et al., 2016; Zhou et al., 2017; Bai et al., 2020) (Figure 1B, eq. 1 and eq. 2). Melchiorre (Kandukuri et al., 2015) and co-workers have disclosed the formation of the electron donor-acceptor (EDA) complex between indoles and electron-deficient benzylbromides and reported a metal-free photo-catalyzed 
Pan et al.

2-Alkylation of 3-Alkyindoles with Inactivated Alkenes

TABLE 1 | Optimization of reaction conditions. ${ }^{a}$

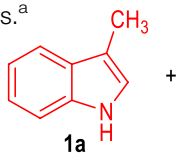

$$
\overbrace{\mathrm{Ph}} \underset{\text { acid }}{\stackrel{\text { aclvent, } 30^{\circ} \mathrm{C}, 12 \mathrm{~h}}{\longrightarrow}}
$$<smiles>Cc1c(C(C)(c2ccccc2)c2ccccc2)[nH]c2ccccc12</smiles>

aa

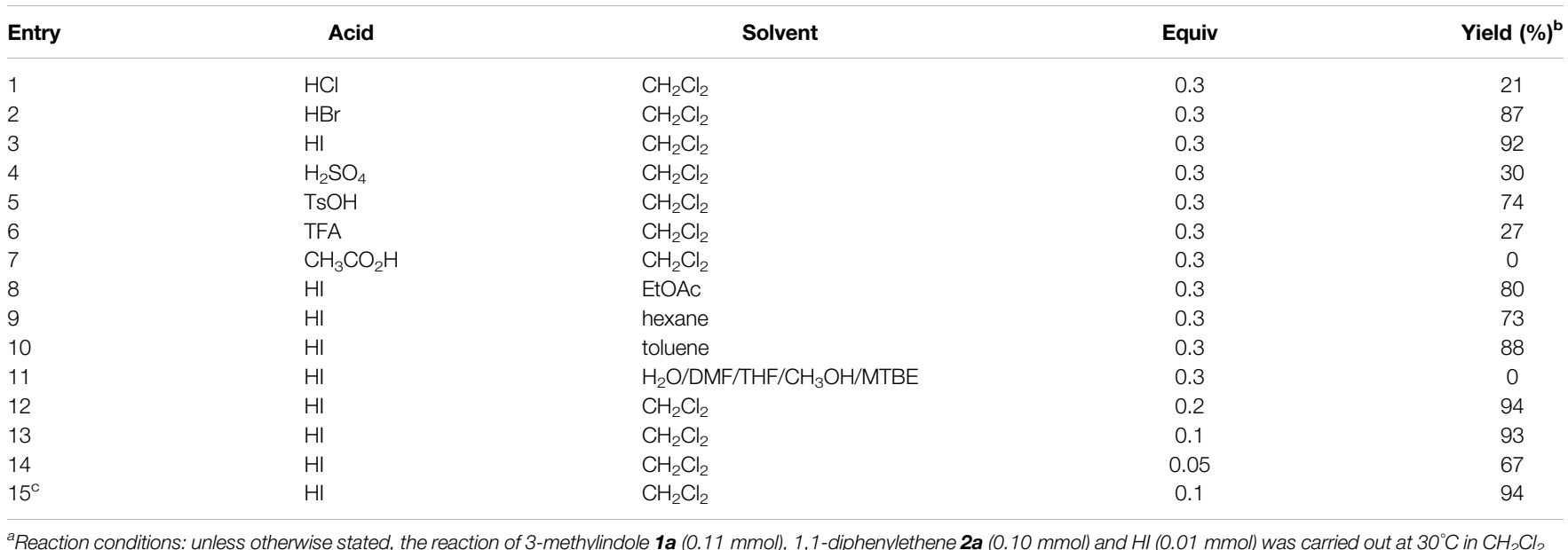

$(1.0 \mathrm{ml})$ for $12 \mathrm{~h}$.

${ }^{\mathrm{b}}$ /solated yield of $\mathbf{3 a}$.

cat $25^{\circ} \mathrm{C}$.<smiles>C/C=C(/N)C(C)(c1ccccc1)c1ccccc1</smiles>

Ba. $94 \%$<smiles>Cc1ccc2[nH]c(C(C)(c3ccccc3)c3ccccc3)c(C)c2c1</smiles><smiles>Cc1c(C(C)(c2ccccc2)c2ccccc2)[nH]c2ccc(F)cc12</smiles><smiles>Cc1c(C(C)(c2ccccc2)c2ccccc2)[nH]c2ccc(Cl)cc12</smiles>

Bb. $90 \%$

sc. $71 \%$

Bd, $74 \%$<smiles>Cc1ccc2c(C)c(C(C)(c3ccccc3)c3ccccc3)[nH]c2c1</smiles>

Be, $83 \%$<smiles>COc1ccc2c(C)c(C(C)(c3ccccc3)c3ccccc3)[nH]c2c1</smiles><smiles>Cc1c(C(C)(c2ccccc2)c2ccccc2)[nH]c2cc(F)ccc12</smiles><smiles>Cc1c(C(C)(c2ccccc2)c2ccccc2)[nH]c2cc(Cl)ccc12</smiles>

jg. $91 \%$

th. $77 \%$<smiles>Cc1c(C(C)(c2ccccc2)c2ccccc2)[nH]c2c(C)cccc12</smiles><smiles>Cc1c(C(C)(c2ccccc2)c2ccccc2)[nH]c2c(Cl)cccc12</smiles><smiles>Cc1c(C(C)(c2ccccc2)c2ccccc2)[nH]c2c(Br)cccc12</smiles><smiles>[R]c1cccc2[nH]c(C(C)(c3ccccc3)c3ccccc3)c(C)c12</smiles>

$3 \mathrm{l}, \mathrm{R}=\mathrm{Cl}, 75 \%$

$3 \mathrm{~m}, \mathrm{R}=\mathrm{Br}, 66 \%$<smiles>CCc1c(C(C)(c2ccccc2)c2ccccc2)[nH]c2ccccc12</smiles><smiles>CC(=O)Cc1c(C(C)(c2ccccc2)c2ccccc2)[nH]c2ccccc12</smiles>

Bn. $62 \%$

Bo. $60 \%$<smiles>Cc1c(C(C)(c2ccccc2)c2ccccc2)[nH]c2ccc([N+](=O)[O-])cc12</smiles>

No product<smiles>CC(c1ccccc1)(c1ccccc1)c1[nH]c2ccccc2c1C(=O)OCl</smiles>

SCHEME 1 | Scope of Indole 1. ${ }^{\text {a }}{ }^{a}$ Reaction conditions as stated in Table 1, entry 15. Yields are isolated yields after purification by column chromatography.

Frontiers in Chemistry | www.frontiersin.org

3

February 2022 | Volume 10 | Article 860764 


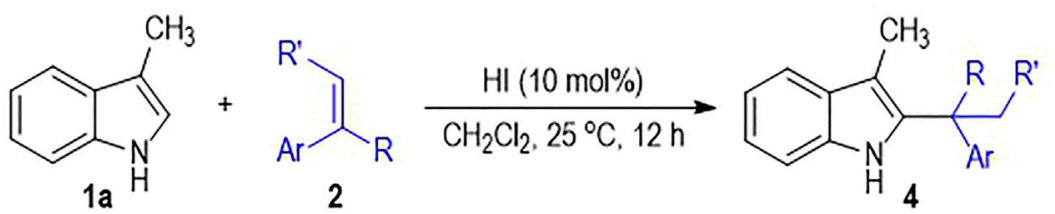<smiles>Cc1ccc(C(C)(c2ccccc2)c2[nH]c3ccccc3c2C)cc1</smiles><smiles>Cc1c(C(C)(c2ccccc2)c2ccc(-c3ccccc3)cc2)[nH]c2ccccc12</smiles><smiles>COc1ccc(C(C)(c2ccccc2)c2[nH]c3ccccc3c2C)cc1</smiles><smiles>Cc1c(C(C)(c2ccccc2)c2ccc(F)cc2)[nH]c2ccccc12</smiles><smiles>C/C=C\C(=C/C)c1cccc(C(C)(c2ccccc2)c2ccccc2)c1C</smiles>

4 e, $86 \%$<smiles>[R]c1ccc(C(C)(C)c2[nH]c3ccccc3c2C)cc1</smiles><smiles>Cc1c(C(C)(c2ccccc2)c2cccc(Cl)c2)[nH]c2ccccc12</smiles>

4f, $47 \%$<smiles>CCC(c1ccccc1)(c1ccc(C)cc1)c1[nH]c2ccccc2c1C</smiles><smiles>Cc1c(C(C)(c2ccccc2)c2ccc3ccccc3c2)[nH]c2ccccc12</smiles><smiles>Cc1c(C(C)(c2ccccc2)c2cccs2)[nH]c2ccccc12</smiles>

4h. $62 \%$<smiles>Cc1ccc(C(C)(c2ccc(C)cc2)c2[nH]c3ccccc3c2C)cc1</smiles><smiles>Cc1c(C(C)(c2ccc(F)cc2)c2ccc(F)cc2)[nH]c2ccccc12</smiles>

SCHEME 2 | Scope of Alkenes 2. ${ }^{\text {a }}{ }^{a}$ Reaction conditions as stated in Table 1, entry 15. Yields are isolated yields after purification by column chromatography.

direct indole C2-alkylation via formation of this EDA complex (eq. 3). Zhang (Wang et al., 2016) and co-workers reported in 2016 the organic semiconductor-catalyzed, visible lightpromoted indole $\mathrm{C} 2$-alkylation with 2-bromomalanates (eq. 4). Recently, Glorius (James et al., 2019) and co-workers used the pyridinium salt as the EDA complex acceptor and realized the indole $\mathrm{C} 2$-alkylation reaction under basic conditions with white light irradiation (eq. 5). To the best of our knowledge, the direct and metal-free C2-alkylation of indoles with unactivated alkenes has not been disclosed.

Herein, we report an acid-promoted regioselective C2alkylation reaction of unprotected indoles 1 (Figure 1C). Unactivated alkenes $\mathbf{2}$ are used as the alkylation reagent, with no sacrificing atoms or functional groups lost during this transformation. The use of EDA acceptors can be avoided in this protocol. A traceless and inexpensive $\mathrm{HI}$ is used in a catalytic amount as the sole reaction catalyst. The C2-branched alkylation products $\mathbf{3}$ or $\mathbf{4}$ bearing a tertiary carbon center are afforded in excellent regioselective fashion with good to excellent isolated yields. The reaction features excellent atom-economy and C2regioselectivity.
The reaction was initially carried out by using 3 methylindole $\mathbf{1 a}$ and 1,1-diphenylethene $\mathbf{2 a}$ as the substrates in dichloromethane under the catalysis of different organic and inorganic acids (Table 1, entries 1-7). To our delight, the indole C2-branched alkylation product 3a can be obtained in promising yields with a variety of strong acids after stirring at $30^{\circ} \mathrm{C}$ for $12 \mathrm{~h}$ (entries 1-6). The target product of 3 a could be afforded in $21 \%$ yield in the presence of $30 \mathrm{~mol} \%$ of $\mathrm{HCl}$ acid (entry 1). The yield of $\mathbf{3 a}$ could be dramatically improved to $87 \%$ when switching the $\mathrm{HCl}$ into $\mathrm{HBr}$ (entry 2). Gratifyingly, the product 3a was obtained in $92 \%$ yield when using $\mathrm{HI}$ as the acid catalyst (entry 3 ). Other organic or inorganic acids gave the desired product $\mathbf{3 a}$ in lower yields (entries 4-6). Notably, the reaction could not happen when using acetic acid as the reaction catalyst, which is probably due to its weak acidity (entry 7). A diversity of organic solvents could be used as the reaction mediate (entries $8-11$ ). For example, the reaction went on smoothly in the solvents of EtOAc, hexane and toluene, with the desired product 3a afforded in good yields (entries 8-10). However, solvents with high polarities such as $\mathrm{H}_{2} \mathrm{O}$, DMF, 


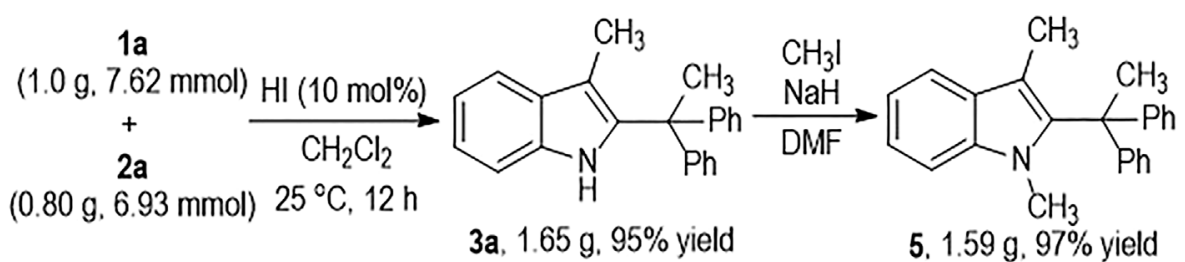

SCHEME 3 | Gram-Scale Synthesis of $\mathbf{3 a}$ and Its Synthetic Transformation.

THF, $\mathrm{CH}_{3} \mathrm{OH}$ and MTBE could not be used for this transformation (entry 11). The amount of the HI catalyst could be decreased to $0.1 \mathrm{~mol} \%$ without obvious erosion of the product yield (entries 12-13). Further decreasing the amount of the HI to $0.05 \mathrm{~mol} \%$ resulted in significant loss of the yield (entry 14). The reaction temperature could also be decreased to $25^{\circ} \mathrm{C}$ with the desired product of $\mathbf{3 a}$ afforded in an even higher yield (entry 15).

Having identified the optimal reaction condition for the HIinduced indole C2-alkylation, we next evaluated the scope of this transformation using indole substrates $\mathbf{1}$ bearing different substituents (Scheme 1). Both electron-donating and electronwithdrawing substituents are well tolerated on the benzene rings of the indole structure, with the target $\mathrm{C} 2$-alkylated indole products afforded in moderate to excellent yields (Scheme 1, 3a to $\mathbf{3 m}$ ). We also examined the effect of the substitution position of the $\mathrm{C} 5$ with $\mathrm{NO}_{2}$ group, but gave no desired product. The C3-methyl group on the indole molecule can be changed into other alkyl groups, with the desired C2-alkylated indole products afforded in a bit lower yields (e.g., 3n to 3o). However, switching the C3-methyl group on the reaction substrates into a C3-phenyl group resulted in no formation of the target product.

The alkene substrates $\mathbf{2}$ can also tolerate diverse substituents and substitution patterns (Scheme 2). Various substituents can be introduced to the para-and meta-positions of the phenyl rings on 2a, with the corresponding products afforded in good to excellent yields (Scheme 2, 4a to $\mathbf{4 f}$ ). However, installing substituents on the ortho-position of the phenyl rings on 2 a leads to no formation of the desired products, which is probably due to the substantially increased steric hindrance during the C2-branched product formation process. One of the phenyl rings on $2 \mathrm{a}$ can be switched into a naphthyl or a thiophenyl group with retention of the good to excellent product yields ( $4 \mathrm{~g}$ to $4 \mathbf{h}$ ). To our delight, one of the two aryl groups on the alkene substrates can be replaced by a methyl group without much erosion on the product yield (4i to $\mathbf{4 j}$ ). It is worth noting that the internal alkene of 1,1-diphenylpropene also works well in this photoinduced indole $\mathrm{C} 2$-alkylation process, with the target product $\mathbf{4 k}$ afforded in $55 \%$ yield. It is not surprising that the 1,1diarylethenes bearing two substituted phenyl groups generally give the desired indole $\mathrm{C} 2$-branched alkylation products in excellent yields (4l to $\mathbf{4 m}$ ).

The HI-induced C2-alkylation reaction of the 3-methylindole 1a with $\mathbf{2 a}$ can be carried out at Gram scales to give the functionalized indole product $\mathbf{3 a}$ in an excellent yield (Scheme 3). The indole $\mathrm{NH}$ group on $\mathbf{3 a}$ can be efficiently protected by
$\mathrm{CH}_{3} \mathrm{I}$ and the $\mathrm{N}$-methylindole product 5 can be afforded in almost quantitative yield.

\section{CONCLUSION}

In summary, we have disclosed a metal-free reaction for the synthesis of 2-alkylation of 3-alkylindole derivatives. 1,1Disubstituted alkenes are used as the alkylation reagent with the C2-branched alkylated indole products afforded in generally good to excellent yields with excellent Markovnikov regioselectivity. A catalytic amount of the commercially available and inexpensive HI is used as the sole reaction catalyst. Further investigations towards the applications of the C2-functionalized indole molecules are in progress in our laboratory.

\section{DATA AVAILABILITY STATEMENT}

The original contributions presented in the study are included in the article/Supplementary Material, further inquiries can be directed to the corresponding author.

\section{AUTHOR CONTRIBUTIONS}

XP conducted most of the experiments. QL and YN participated in some of the experiments. XP conceptualized and directed the whole project. XP drafted the manuscript. All of the authors contributed in scientific discussions.

\section{FUNDING}

We acknowledge financial support from the Program of Introducing Talents of Discipline to Universities of China (111 Program, D20023) at Guizhou University, Frontiers Science Center for Asymmetric Synthesis and Medicinal Molecules, Department of Education, Guizhou Province (Qianjiaohe KY (2020)004), and Guizhou University (China).

\section{SUPPLEMENTARY MATERIAL}

The Supplementary Material for this article can be found online at: https://www.frontiersin.org/articles/10.3389/fchem.2022.860764/ full\#supplementary-material 


\section{REFERENCES}

Ackermann, L., and Lygin, A. V. (2011). Ruthenium-Catalyzed Direct C-H Bond Arylations of Heteroarenes. Org. Lett. 13, 3332-3335. doi:10.1021/ol2010648

Austin, J. F., and MacMillan, D. W. C. (2002). Enantioselective Organocatalytic Indole Alkylations. Design of a New and Highly Effective Chiral Amine for Iminium Catalysis. J. Am. Chem. Soc. 124, 1172-1173. doi:10.1021/ja017255c

Bai, J.-F., Zhao, L., Wang, F., Yan, F., Kano, T., Maruoka, K., et al. (2020). Organocatalytic Formal $(3+2)$ Cycloaddition toward Chiral Pyrrolo[1,2-A] indoles via Dynamic Kinetic Resolution of Allene Intermediates. Org. Lett. 22, 5439-5445. doi:10.1021/acs.orglett.0c01812

Bandini, M., and Eichholzer, A. (2009). Catalytic Functionalization of Indoles in a New Dimension. Angew. Chem. Int. Edition 48, 9608-9644. doi:10.1002/anie. 200901843

Bartoli, G., Bencivenni, G., and Dalpozzo, R. (2010). Organocatalytic Strategies for the Asymmetric Functionalization of Indoles. Chem. Soc. Rev. 39, 4449-4465. doi: $10.1039 / \mathrm{b} 923063 \mathrm{~g}$

Bartoli, G., Bosco, M., Giuli, S., Giuliani, A., Lucarelli, L., Marcantoni, E., et al. (2005). Efficient Preparation of 2-Indolyl-1-Nitroalkane Derivatives Employing Nitroalkenes as Versatile Michael Acceptors: New Practical Linear Approach to Alkyl 9H- $\beta$-Carboline-4-Carboxylate. J. Org. Chem. 70, 1941-1944. doi:10. 1021/jo048776w

Deprez, N. R., Kalyani, D., Krause, A., and Sanford, M. S. (2006). Room Temperature Palladium-Catalyzed 2-Arylation of Indoles. J. Am. Chem. Soc. 128, 4972-4973. doi:10.1021/ja060809x

Ding, Z., and Yoshikai, N. (2012). Mild and Efficient C2-Alkenylation of Indoles with Alkynes Catalyzed by a Cobalt Complex. Angew. Chem. Int. Ed. 51, 4698-4701. doi:10.1002/anie.201200019

Doyle, M. P., Duffy, R., Ratnikov, M., and Zhou, L. (2010). Catalytic Carbene Insertion into C-H Bonds. Chem. Rev. 110, 704-724. doi:10.1021/cr900239n

Evans, D. A., Fandrick, K. R., and Song, H.-J. (2005). Enantioselective Friedel-Crafts Alkylations of $\alpha, \beta$-Unsaturated 2-Acyl Imidazoles Catalyzed by Bis(oxazolinyl)pyridine-Scandium(III) Triflate Complexes. J. Am. Chem. Soc. 127, 8942-8943. doi:10.1021/ja052433d

Gensch, T., Klauck, F. J. R., and Glorius, F. (2016). Cobalt-Catalyzed C-H Thiolation through Dehydrogenative Cross-Coupling. Angew. Chem. Int. Ed. 55, 11287-11291. doi:10.1002/anie.201605193

James, M. J., Strieth-Kalthoff, F., Sandfort, F., Klauck, F. J. R., Wagener, F., and Glorius, F. (2019). Visible-Light-Mediated Charge Transfer Enables C-C Bond Formation with Traceless Acceptor Groups. Chem. Eur. J. 25, 8240-8244. doi:10.1002/chem.201901397

Jiao, L., and Bach, T. (2011). Palladium-Catalyzed Direct 2-Alkylation of Indoles by Norbornene-Mediated Regioselective Cascade C-H Activation. J. Am. Chem. Soc. 133, 12990-12993. doi:10.1021/ja2055066

Johansen, M. B., and Kerr, M. A. (2010). Direct Functionalization of Indoles: Copper-Catalyzed Malonyl Carbenoid Insertions. Org. Lett. 12, 4956-4959. doi:10.1021/ol1020948

Joucla, L., and Djakovitch, L. (2009). Transition Metal-Catalysed, Direct and Site-Selective N1-, C2- or C3-Arylation of the Indole Nucleus: 20 Years of Improvements. Adv. Synth. Catal. 351, 673-714. doi:10.1002/adsc. 200900059

Kandukuri, S. R., Bahamonde, A., Chatterjee, I., Jurberg, I. D., Escudero-Adán, E. C., and Melchiorre, P. (2015). X-Ray Characterization of an Electron DonorAcceptor Complex that Drives the Photochemical Alkylation of Indoles. Angew. Chem. Int. Ed. 54, 1485-1489. doi:10.1002/anie.201409529

Kimura, M., Futamata, M., Mukai, R., and Tamaru, Y. (2005). Pd-Catalyzed C3Selective Allylation of Indoles with Allyl Alcohols Promoted by Triethylborane. J. Am. Chem. Soc. 127, 4592-4593. doi:10.1021/ja0501161

Kong, L., Yu, S., Tang, G., Wang, H., Zhou, X., and Li, X. (2016). Cobalt(III)Catalyzed C-C Coupling of Arenes with 7-Oxabenzonorbornadiene and 2Vinyloxirane via C-H Activation. Org. Lett. 18, 3802-3805. doi:10.1021/acs. orglett.6b01806

Kusurkar, R. S., Alkobati, N. A. H., Gokule, A. S., and Puranik, V. G. (2008). Use of the Pictet-Spengler Reaction for the Synthesis of 1,4-Disubstituted-1,2,3,4Tetrahydro- $\beta$-Carbolines and 1,4-Disubstituted- $\beta$-Carbolines: Formation of $\gamma$-carbolines. Tetrahedron 64, 1654-1662. doi:10.1016/j.tet.2007.12.008
Lane, B. S., and Sames, D. (2004). Direct C-H Bond Arylation: Selective PalladiumCatalyzed C2-Arylation of N-Substituted Indoles. Org. Lett. 6, 2897-2900. doi:10.1021/ol0490072

Lebrasseur, N., and Larrosa, I. (2008). Room Temperature and Phosphine Free Palladium Catalyzed Direct C-2 Arylation of Indoles. J. Am. Chem. Soc. 130, 2926-2927. doi:10.1021/ja710731a

Lerch, S., Unkel, L. N., and Brasholz, M. (2014). Tandem Organocatalysis and Photocatalysis: An Anthraquinone-Catalyzed Indole-C3-Alkylation/ Photooxidation/1,2-Shift Sequence. Angew. Chem. Int. Ed. 53, 6558-6562. doi:10.1002/anie.201402920

Li, B., Ma, J., Xie, W., Song, H., Xu, S., and Wang, B. (2013b). Regioselective C2 Oxidative Olefination of Indoles and Pyrroles through Cationic Rhodium(III)Catalyzed CH Bond Activation. Chem. Eur. J. 19, 11863-11868. doi:10.1002/ chem.201301987

Li, B., Ma, J., Xie, W., Song, H., Xu, S., and Wang, B. (2013a). Ruthenium-Catalyzed Regioselective C2 Alkenylation of Indoles and Pyrroles via C-H Bond Functionalization. J. Org. Chem. 78, 9345-9353. doi:10.1021/jo401579m

Li, T., Wang, Z., Qin, W.-B., and Wen, T.-B. (2016). Rhodium-Catalyzed/CopperMediated Selective C2 Alkynylation of Indoles and C1 Alkynylation of Carbazoles With $\gamma$-Substitutedtert-Propargyl Alcohols. ChemCatChem 8, 2146-2154. doi: $10.1002 /$ cctc. 201600218

Liang, L., Fu, S., Lin, D., Zhang, X.-Q., Deng, Y., Jiang, H., et al. (2014). Ruthenium(II)-Catalyzed Direct Addition of Indole/Pyrrole C2-H Bonds to Alkynes. J. Org. Chem. 79, 9472-9480. doi:10.1021/jo501460h

Lin, Q., Chu, L., and Qing, F.-L. (2013). Direct Introduction of Ethoxycarbonyldifluoromethyl-Group to Heteroarenes with Ethyl Bromodifluoroacetate via Visible-Light Photocatalysis. Chin. J. Chem. 31, 885-891. doi:10.1002/cjoc.201300411

Ma, Y.-M., Liang, X.-A., Kong, Y., and Jia, B. (2016). Structural Diversity and Biological Activities of Indole Diketopiperazine Alkaloids from Fungi. J. Agric. Food Chem. 64, 6659-6671. doi:10.1021/acs.jafc.6b01772

Maehara, A., Tsurugi, H., Satoh, T., and Miura, M. (2008). Regioselective C-H Functionalization Directed by a Removable Carboxyl Group: PalladiumCatalyzed Vinylation at the Unusual Position of Indole and Related Heteroaromatic Rings. Org. Lett. 10, 1159-1162. doi:10.1021/ol8000602

Moran, J., Suen, T., and Beauchemin, A. M. (2006). Photoinduced 1,4-Additions of Indoles to Enones. J. Org. Chem. 71, 676-679. doi:10.1021/jo0521044

Nakao, Y., Kanyiva, K. S., Oda, S., and Hiyama, T. (2006). Hydroheteroarylation of Alkynes under Mild Nickel Catalysis. J. Am. Chem. Soc. 128, 8146-8147. doi:10. 1021/ja0623459

Pan, S., Ryu, N., and Shibata, T. (2012). Ir(I)-Catalyzed C-H Bond Alkylation of C2-Position of Indole with Alkenes: Selective Synthesis of Linear or Branched 2-Alkylindoles. J. Am. Chem. Soc. 134, 17474-17477. doi:10.1021/ja308742x

Phipps, R. J., Grimster, N. P., and Gaunt, M. J. (2008). Cu(II)-Catalyzed Direct and Site-Selective Arylation of Indoles under Mild Conditions. J. Am. Chem. Soc. 130, 8172-8174. doi:10.1021/ja801767s

Sauermann, N., González, M. J., and Ackermann, L. (2015). Cobalt(III)-Catalyzed C-H Alkynylation with Bromoalkynes under Mild Conditions. Org. Lett. 17, 5316-5319. doi:10.1021/acs.orglett.5b02678

Schramm, Y., Takeuchi, M., Semba, K., Nakao, Y., and Hartwig, J. F. (2015). AntiMarkovnikov Hydroheteroarylation of Unactivated Alkenes with Indoles, Pyrroles, Benzofurans, and Furans Catalyzed by a Nickel- $N$-Heterocyclic Carbene System. J. Am. Chem. Soc. 137, 12215-12218. doi:10.1021/jacs. 5 b08039

Shao, C., Shi, G., Zhang, Y., Pan, S., and Guan, X. (2015). Palladium-Catalyzed C-H Ethoxycarbonyldifluoromethylation of Electron-Rich Heteroarenes. Org. Lett. 17, 2652-2655. doi:10.1021/acs.orglett.5b01024

Soni, V., Sharma, D. M., and Punji, B. (2018). Nickel-Catalyzed Regioselective C(2)-H Difluoroalkylation of Indoles with Difluoroalkyl Bromides. Chem. Asian J. 13, 2516-2521. doi:10.1002/asia.201800504

Straathof, N. J. W., Gemoets, H. P. L., Wang, X., Schouten, J. C., Hessel, V., and Noël, T. (2014). Rapid Trifluoromethylation and Perfluoroalkylation of FiveMembered Heterocycles by Photoredox Catalysis in Continuous Flow. ChemSusChem 7, 1612-1617. doi:10.1002/cssc.201301282

Su, Y.-M., Hou, Y., Yin, F., Xu, Y.-M., Li, Y., Zheng, X., et al. (2014). Visible LightMediated C-H Difluoromethylation of Electron-Rich Heteroarenes. Org. Lett. 16, 2958-2961. doi:10.1021/ol501094z 
Sun, B., Yoshino, T., Matsunaga, S., and Kanai, M. (2015). A Cp ${ }^{\star} \mathrm{CoI} 2-\mathrm{Dimer}$ as a Precursor for Cationic Co(iii)-Catalysis: Application to C-H Phosphoramidation of Indoles. Chem. Commun. 51, 4659-4661. doi:10. 1039/C4CC10284C

Sun, B., Yoshino, T., Matsunaga, S., and Kanai, M. (2014). Air-Stable Carbonyl(pentamethylcyclopentadienyl)cobalt Diiodide Complex as a Precursor for Cationic (Pentamethylcyclopentadienyl)Cobalt(III) Catalysis: Application for Directed C-2 Selective $\mathrm{CH}$ Amidation of Indoles. Adv. Synth. Catal. 356, 1491-1495. doi:10.1002/adsc.201301110

Terada, M., and Sorimachi, K. (2007). Enantioselective Friedel-Crafts Reaction of Electron-Rich Alkenes Catalyzed by Chiral Brønsted Acid. J. Am. Chem. Soc. 129, 292-293. doi:10.1021/ja0678166

Tolnai, G. L., Ganss, S., Brand, J. P., and Waser, J. (2013). C2-Selective Direct Alkynylation of Indoles. Org. Lett. 15, 112-115. doi:10.1021/ol3031389

Wang, L., Huang, W., Li, R., Gehrig, D., Blom, P. W. M., Landfester, K., et al. (2016). Structural Design Principle of Small-Molecule Organic Semiconductors for Metal-free, Visible-Light-Promoted Photocatalysis. Angew. Chem. Int. Ed. 55, 9783-9787. doi:10.1002/anie.201603789

Wang, X., Lane, B. S., and Sames, D. (2005). Direct C-Arylation of Free (NH)Indoles and Pyrroles Catalyzed by $\mathrm{Ar}-\mathrm{Rh}(\mathrm{III})$ Complexes Assembled In Situ. J. Am. Chem. Soc. 127, 4996-4997. doi:10.1021/ja050279p

Wang, Y.-Q., Song, J., Hong, R., Li, H., and Deng, L. (2006). Asymmetric Friedel-Crafts Reaction of Indoles with Imines by an Organic Catalyst. J. Am. Chem. Soc. 128, 8156-8157. doi:10.1021/ja062700v

Wang, Z., and Wang, C. (2021). Manganese/NaOPh Co-catalyzed C2-Selective $\mathrm{C}-\mathrm{H}$ Conjugate Addition of Indoles to $\alpha, \beta$-unsaturated Carbonyls. Green. Synth. Catal. 2, 66-69. doi:10.1016/j.gresc.2021.01.010

Weng, J.-Q., Fan, R.-J., Deng, Q.-M., Liu, R.-R., Gao, J.-R., and Jia, Y.-X. (2016). Enantioselective Friedel-Crafts Alkylation Reactions of 3-Substituted Indoles with Electron-Deficient Alkenes. J. Org. Chem. 81, 3023-3030. doi:10.1021/acs. joc.6b00123

Wong, M. Y., Yamakawa, T., and Yoshikai, N. (2015). Iron-Catalyzed Directed C2Alkylation and Alkenylation of Indole with Vinylarenes and Alkynes. Org. Lett. 17, 442-445. doi:10.1021/ol503395g

Yang, L., Zhao, L., and Li, C.-J. (2010). Palladium-Catalyzed Direct Oxidative Heck-Cassar-Sonogashira Type Alkynylation of Indoles with Alkynes under Oxygen. Chem. Commun. 46, 4184-4186. doi:10.1039/c0cc00014k

Yang, Q.-Q., Marchini, M., Xiao, W.-J., Ceroni, P., and Bandini, M. (2015). Visible-Light-Induced Direct Photocatalytic Carboxylation of Indoles with CBr4/MeOH. Chem. Eur. J. 21, 18052-18056. doi:10.1002/chem. 201503787
Yang, S.-D., Sun, C.-L., Fang, Z., Li, B.-J., Li, Y.-Z., and Shi, Z.-J. (2008). PalladiumCatalyzed Direct Arylation of (Hetero)Arenes with Aryl Boronic Acids. Angew. Chem. Int. Ed. 47, 1473-1476. doi:10.1002/anie.200704619

Yang, Y., and Shi, Z. (2018). Regioselective Direct Arylation of Indoles on the Benzenoid Moiety. Chem. Commun. 54, 1676-1685. doi:10.1039/c7cc08752g

Yoshino, T., Ikemoto, H., Matsunaga, S., and Kanai, M. (2013). Cp ${ }^{*}$ CoIII -Catalyzed C2-Selective Addition of Indoles to Imines. Chem. Eur. J. 19, 9142-9146. doi:10.1002/chem.201301505

Zhang, W., Wei, J., Fu, S., Lin, D., Jiang, H., and Zeng, W. (2015). Highly Stereoselective Ruthenium(II)-Catalyzed Direct C2-Syn-Alkenylation of Indoles with Alkynes. Org. Lett. 17, 1349-1352. doi:10.1021/ol503618m

Zhang, Z.-Z., Liu, B., Wang, C.-Y., and Shi, B.-F. (2015). Cobalt(III)-Catalyzed C2Selective C-H Alkynylation of Indoles. Org. Lett. 17, 4094-4097. doi:10.1021/ acs.orglett.5b02038

Zhou, J., and Tang, Y. (2002). Sidearm Effect: Improvement of the Enantiomeric Excess in the Asymmetric Michael Addition of Indoles to Alkylidene Malonates. J. Am. Chem. Soc. 124, 9030-9031. doi:10.1021/ja026936k

Zhou, X., Fan, Z., Zhang, Z., Lu, P., and Wang, Y. (2016). Construction of Pyrrolo [1,2-a]Indoles via Cobalt(III)-Catalyzed Enaminylation of 1-(Pyrimidin-2-Yl)$1 \mathrm{~h}$-Indoles with Ketenimines and Subsequent Base-Promoted Cyclization. Org. Lett. 18, 4706-4709. doi:10.1021/acs.orglett.6b02353

Zhou, Z., Li, Y., Gong, L., and Meggers, E. (2017). Enantioselective 2-Alkylation of 3-Substituted Indoles with Dual Chiral Lewis Acid/Hydrogen-Bond-Mediated Catalyst. Org. Lett. 19, 222-225. doi:10.1021/acs.orglett.6b03500

Conflict of Interest: The authors declare that the research was conducted in the absence of any commercial or financial relationships that could be construed as a potential conflict of interest.

Publisher's Note: All claims expressed in this article are solely those of the authors and do not necessarily represent those of their affiliated organizations, or those of the publisher, the editors, and the reviewers. Any product that may be evaluated in this article, or claim that may be made by its manufacturer, is not guaranteed or endorsed by the publisher.

Copyright (c) 2022 Pan, Liu and Nong. This is an open-access article distributed under the terms of the Creative Commons Attribution License (CC BY). The use, distribution or reproduction in other forums is permitted, provided the original author(s) and the copyright owner(s) are credited and that the original publication in this journal is cited, in accordance with accepted academic practice. No use, distribution or reproduction is permitted which does not comply with these terms. 